
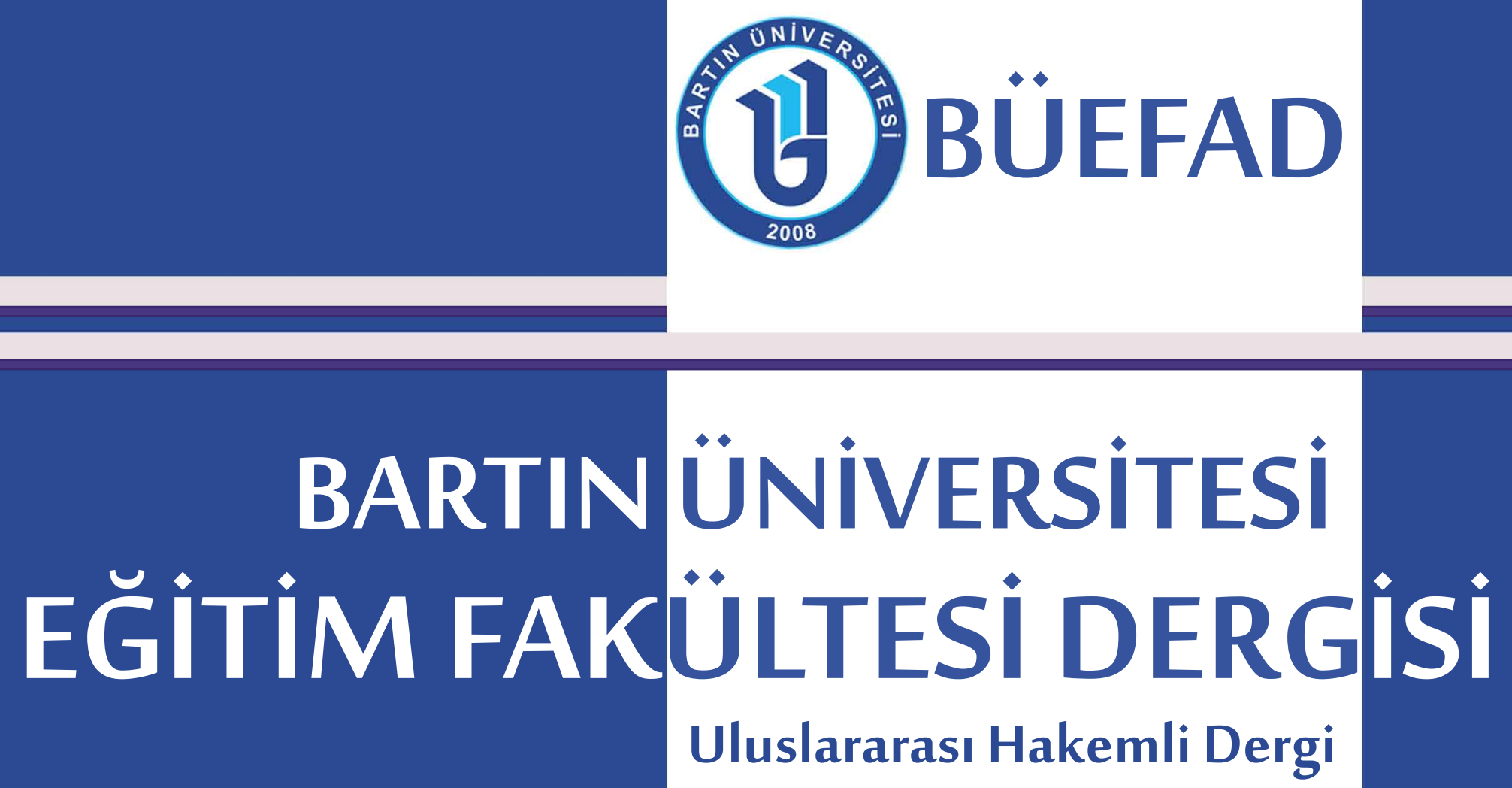

\section{- AYRI BASIM -}

Prof. Dr. Firdevs GÜNES

Doç. Dr. Coskun ARSLAN

Arş. Gör. Ayşe ELï̈şüK

Atılganlık Eğitiminin Üniversite Öğrencilerinin Kişiler Arası Problem Çözme Algılanan Sosyal Destek ve Atılganlık Düzeyleri Üzerine Etkisi
- SPECIAL EDITION -

Prof. Firdevs GUNES

Assoc. Prof. Coskun ARSLAN

RA Ayse ELIUSUK

The Impact of Assertiveness Training on Interpersonal Problem Solving Perceived Social Support and Assertiveness of University Students

ProcessForm

Objectives

Pre-Service

okuma vels echnology

Profession
Verbal Supervision Validity

Study Understanding

Study Investigating Turkish

BARTINUNIVERSITY JOURNAL

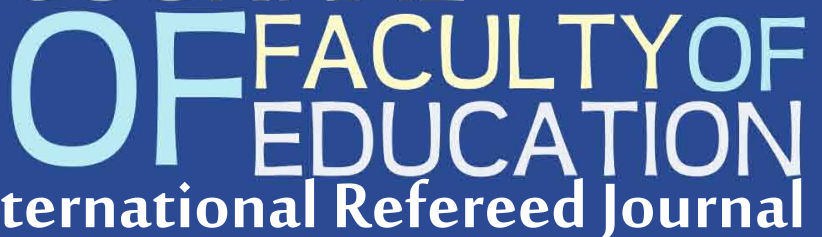

Cilt/Volume: $3 \quad$ Sayı/Issue: 1

Yaz/Summer 2014 ISSN 1308-7177
Attitudes Atyle $^{\text {Style }}$

Teaching Features $^{\text {Features }}$ University

Güvenirlik Geçerlilik

Çalışması Analysis

Example Speech
OzyeterlilikEleştirel 


\section{BARTIN ÜNIVERSİTesi EĞítim FAKüLTESI DERgisi}

BARTIN UNIVERSITY JOURNAL OF FACULTY OF EDUCATION

Cilt/ Volume: 3, Say1/Issue: 1, Yaz / Summer 2014

ISSN:1308-7177

\section{$\underline{\text { Sahibi }}$}

Bartın Üniversitesi Eğitim Fakültesi Adına Prof. Dr. Firdevs GÜNEŞ (Dekan)

Editör

Yrd. Doç. Dr. Sedat BALYEMEZ

\section{Alan Editörleri}

Doç. Dr. Çetin SEMERCi

Doç. Dr. Necati HIRÇA

Doç. Dr. Nuriye SEMERCi

Yrd. Doç. Dr. Ayşe Derya IŞIK

Yrd. Doç. Dr. Meliha KÖSE

Yrd. Doç. Dr. Neslihan USTA

Yrd. Doç. Dr. Sevan NART

Yrd. Doç. Dr. Sinem TARHAN

Yrd. Doç. Dr. Süreyya GENÇ

Yabancı Dil Sorumlusu

Yrd. Doç. Dr. Özge GÜN

\section{Yayıma Hazırlık}

Arş. Gör. Arzu ÇEVIK

Arş. Gör. Ömer KEMiksiz

\section{Sekretarya}

Arş. Gör. Hasan Basri KANSIZOĞLU

\section{Teknik Sorumlular}

Arş. Gör. Barış ÇUKURBAŞı

Arş. Gör. Fatma Gizem KARAOĞLAN YILMAZ

\section{İetişim}

Bartın Üniversitesi Eğitim Fakültesi

74100 BARTIN - TÜRKIYE

e-posta: buefad@bartin.edu.tr

Tel: +903782235219

Bartın Üniversitesi Eğitim Fakültesi Dergisi (BÜEFAD), yılda iki kez yayımlanan uluslararası hakemli bir dergidir. Yazıların sorumluluğu, yazarlarına aittir.
Owner

On Behalf of Bartin University Faculty of Education Prof. Firdevs GUNES (Dean)

$\underline{\text { Editor }}$

Asst. Prof. Sedat BALYEMEZ

Field Editors

Assoc. Prof. Cetin SEMERCI

Assoc. Prof. Necati HIRCA

Assoc. Prof. Nuriye SEMERCI

Asst. Prof. Ayse Derya ISIK

Asst. Prof. Meliha KOSE

Asst. Prof. Neslihan USTA

Asst. Prof. Sevan NART

Asst. Prof. Sinem TARHAN

Asst. Prof. Sureyya GENC

Foreign Language Specialist

Asst. Prof. Ozge GUN

Preparing for Publication

RA. Arzu CEVIK

RA. Omer KEMIKSIZ

Secretary

RA. Hasan Basri KANSIZOGLU

$\underline{\text { Technical Assistants }}$

RA. Baris CUKURBASI

RA. Fatma Gizem KARAOGLAN YILMAZ

Contact

Bartin University Faculty of Education 74100 BARTIN - TURKEY

e-mail: buefad@bartin.edu.tr

Tel: +90 3782235219

Bartin University Journal of Faculty of Education (BUJFED) is a international refereed journal that is published two times a year. The responsibility lies with the authors of papers. 


\section{DiZINLENME VE LISTELENME / INDEXING AND LISTING}

Bartın Üniversitesi Eğitim Fakültesi Dergisi, aşağıdaki indeksler tarafından dizinlenmekte ve listelenmektedir. / Bartin University Journal of Faculty of Education is indexed and listed by the following indexes.

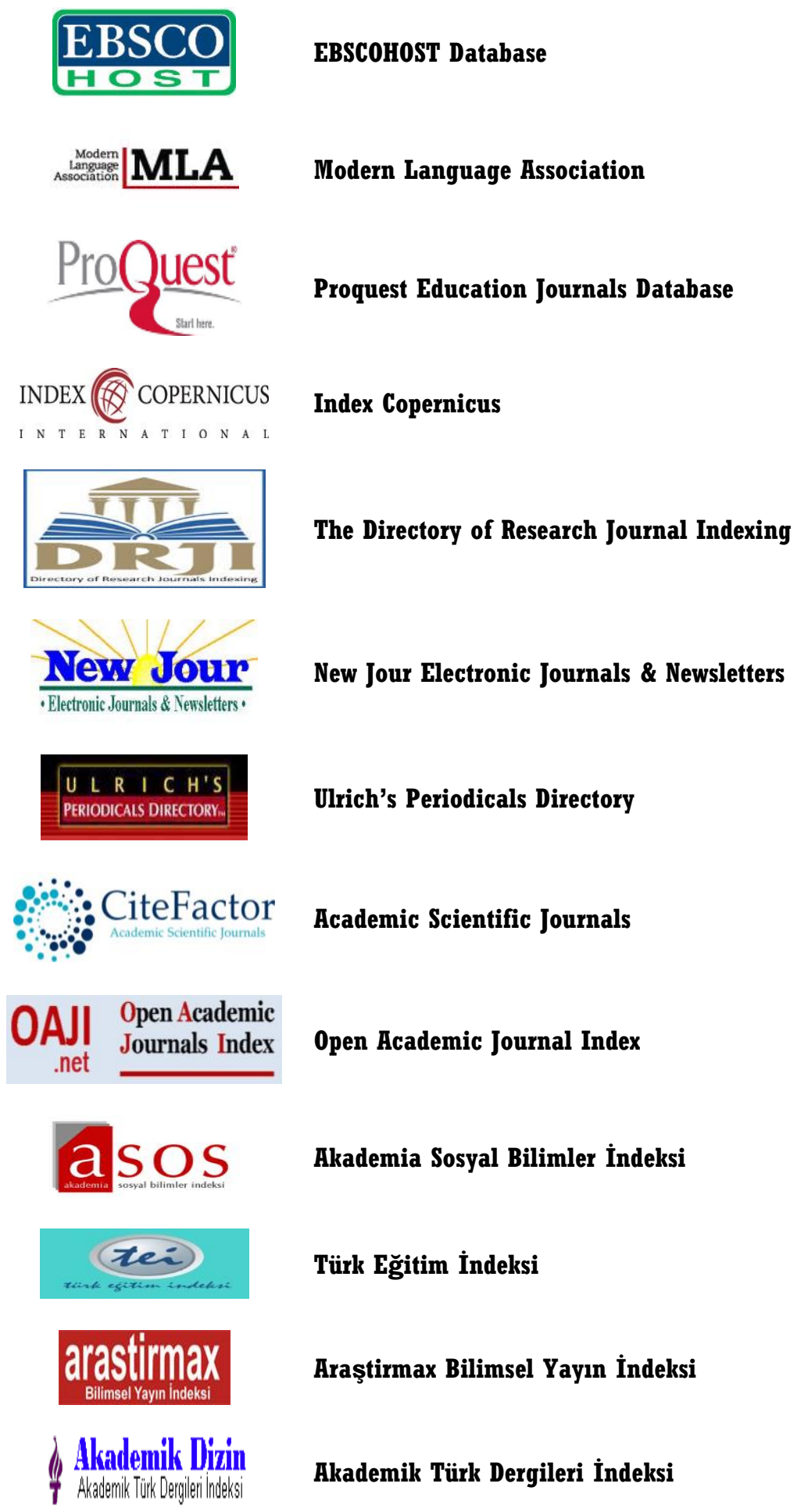


YAYIN DANIŞMA KURULU / EDITORIAL ADVISORYBOARD

Prof. Dr. Ahmet ARIKAN

Prof. Dr. Ahmet GÜNŞEN

Prof. Dr. Ahmet SABAN

Prof. Dr. Aziz KILINÇ

Prof. Dr. Bilgin Ünal iBRET

Prof. Dr. Cemal TOSUN

Prof. Dr. Firdevs GÜNEŞ

Prof. Dr. Firdevs KARAHAN

Prof. Dr. Ahmet KIRKILIÇ

Prof. Dr. Hayati AKYOL

Prof. Dr. Hüseyin ALKAN

Prof. Dr. M. Fatih TAŞAR

Prof. Dr. Mimar TÜRKKAHRAMAN

Prof. Dr. Murat ÖZBAY

Prof. Dr. Ramazan KAPLAN

Prof. Dr. Recai DOĞAN

Prof. Dr. Safure BULUT

Prof. Dr. Sebahattin ARIBAŞ

Prof. Dr. Selahattin TURAN

Prof. Dr. Selma YEL

Prof. Dr. Şefik YAŞAR

Prof. Dr. Yavuz TAŞKESENLIGIL

Doç. Dr. Bahri ATA

Doç. Dr. Çavuş ŞAHIN

Doç. Dr. Çetin SEMERCi

Doç. Dr. Emine KOLAÇ

Doç. Dr. Erol DURAN

Doç. Dr. Eyyüp COŞKUN

Doç. Dr. Kubilay YAZICI

Doç. Dr. Neşe TERTEMiz

Doç. Dr. Nuriye SEMERCi

Doç. Dr. Sabri SIDEKLi

Doç. Dr. Tolga GÜYER
Gazi Üniversitesi

Trakya Üniversitesi

N. Erbakan Üniversitesi

ÇOMÜ

Kastamonu Üniversitesi

Ankara Üniversitesi

Bartın Üniversitesi

Sakarya Üniversitesi

Atatürk Üniversitesi

Gazi Üniversitesi

Dokuz Eylül Üniversitesi

Gazi Üniversitesi

Akdeniz Üniversitesi

Gazi Üniversitesi

Bartın Üniversitesi

Ankara Üniversitesi

ODTÜ

Adıyaman Üniversitesi

Osmangazi Üniversitesi

Gazi Üniversitesi

Anadolu Üniversitesi

Atatürk Üniversitesi

Gazi Üniversitesi

ÇOMÜ

Bartın Üniversitesi

Anadolu Üniversitesi

Uşak Üniversitesi

Mustafa Kemal Üniversitesi

Niğde Üniversitesi

Gazi Üniversitesi

Bartın Üniversitesi

Muğla S. Koçman Üniversitesi

Gazi Üniversitesi 


\section{BU SAYININ HAKEMLERI / REFEREES OFTHIS ISSUE}

Prof. Dr. Ahmet KAÇAR

Prof. Dr. Adnan BAKi

Prof. Dr. Fatma AÇIK

Prof. Dr. Firdevs GÜNEŞ

Prof. Dr. Firdevs KARAHAN

Prof. Dr. Hasan BACANLI

Prof. Dr. Yusuf BUDAK

Doç. Dr. Ali TAŞ

Doç. Dr. Çetin SEMERCi

Doç. Dr. Ebru KILIÇ ÇAKMAK

Doç. Dr. Eyyüp COŞKUN

Doç. Dr. Halit KARATAY

Doç. Dr. Gökhan DEMIRCioĞLU

Doç. Dr. Levent ERASLAN

Doç. Dr. Mehmet Ali ÇAKMAK

Doç. Dr. Mehmet Altan KURNAZ

Doç. Dr. Mustafa ULUSOY

Doç. Dr. Mübin KIYICI

Doç. Dr. Necati HIRÇA

Doç. Dr. Nuriye SEMERCi

Doç. Dr. Orhan AKINOĞLU

Doç. Dr. Özay KARADAĞ

Doç. Dr. Özlem ÇAKMAK

Doç. Dr. Sabri SIDEKLI

Doç. Dr. Yüksel GÖĞEBAKAN

Yrd. Doç. Dr. Abdullah Çağrı BiBBER

Yrd. Doç. Dr. Ahmet YIKMIŞ

Yrd. Doç. Dr. Ahmet AKKAYA

Yrd. Doç. Dr. Ali Rıza ŞEKERCi

Yrd. Doç. Dr. Aslıhan SABAN

Yrd. Doç. Dr. Aynur KOLBURAN GEÇER

Yrd. Doç. Dr. Ayşe Derya IŞIK

Yrd. Doç. Dr. Ayşe GÜLER

Yrd. Doç. Dr. Burcu DUMAN

Yrd. Doç. Dr. Cemal TOSUN

Yrd. Doç. Dr. Çığıl AYKUT

Yrd. Doç. Dr. Devrim AKGÜNDÜZ

Yrd. Doç. Dr. Fulya TOPÇUOĞLU ÜNAL

Yrd. Doç. Dr. Gamze Elif TANINMIŞ

Yrd. Doç. Dr. Güliz AYDIN

Yrd. Doç. Dr. İbrahim GÖKTAŞ

Yrd. Doç. Dr. İlhan YALÇIN
Kastamonu Üniversitesi

Karadeniz Teknik Üniversitesi

Gazi Üniversitesi

Bartın Üniversitesi

Sakarya Üniversitesi

Yıldız Teknik Üniversitesi

Gazi Üniversitesi

Kırıkkale Üniversitesi

Bartın Üniversitesi

Gazi Üniversitesi

Mustafa Kemal Üniversitesi

Abant İzzet Baysal Üniversitesi

Ondokuz Mayıs Üniversitesi

Kırıkkale Üniversitesi

Gazi Üniversitesi

Kastamonu Üniversitesi

Gazi Üniversitesi

Sakarya Üniversitesi

Bartın Üniversitesi

Bartın Üniversitesi

Marmara Üniversitesi

Düzce Üniversitesi

Gazi Üniversitesi

Muğla Sıtkı Koçman Üniversitesi

İnönü Üniversitesi

Kastamonu Üniversitesi

Abant İzzet Baysal Üniversitesi

Adıyaman Üniversitesi

Dumlupınar Üniversitesi

Konya Üniversitesi

Kocaeli Üniversitesi

Bartın Üniversitesi

Kırıkkale Üniversitesi

Bartın Üniversitesi

Bartın Üniversitesi

Gazi Üniversitesi

İstanbul Aydın Üniversitesi

Dumlupınar Üniversitesi

Gazi Üniversitesi

Ordu Üniversitesi

Adnan Menderes Üniversitesi

Ankara Üniversitesi 
Yrd. Doç. Dr. M. Sani ADIGÜZEL

Yrd. Doç. Dr. Mehmet Diyaddin YAŞAR

Yrd. Doç. Dr. Mehmet UMUZDAŞ

Yrd. Doç. Dr. Metin DENIZ

Yrd. Doç. Dr. Murat GENÇ

Yrd. Doç. Dr. Nail iLHAN

Yrd. Doç. Dr. Nalan OKAN AKIN

Yrd. Doç. Dr. Nuray MAMUR

Yrd. Doç. Dr. Özcan KARAASLAN

Yrd. Doç. Dr. Özge GÜN

Yrd. Doç. Dr. Sedat BALYEMEZ

Yrd. Doç. Dr. Semra KIRANLI GÜNGÖR

Yrd. Doç. Dr. Sibel SADI

Yrd. Doç. Dr. Suad SAKALLI GÜMÜŞ

Yrd. Doç. Dr. Sultan Bilge KARA

Yrd. Doç. Dr. Süleyman AVCI

Yrd. Doç. Dr. Şenel ELALDI

Yrd. Doç. Dr. Şeyda GÜL

Yrd. Doç. Dr. Tolga KABACA

Yrd. Doç. Dr. Tuncay Yavuz ÖZDEMiR

Yrd. Doç. Dr. Yakup DOĞAN

Dr. Hayriye Tuğba ÖZTÜRK
İstanbul Aydın Üniversitesi

Kilis 7 Aralık Üniversitesi

Gaziosmanpaşa Üniversitesi

Bartın Üniversitesi

Düzce Üniversitesi

Kilis 7 Aralık Üniversitesi

Niğde Üniversitesi

Pamukkale Üniversitesi

Marmara Üniversitesi

Bartın Üniversitesi

Bartın Üniversitesi

Eskişehir Osmangazi Üniversitesi

Kafkas Üniversitesi

Mustafa Kemal Üniversitesi

Okan Üniversitesi

Marmara Üniversitesi

Cumhuriyet Üniversitesi

Atatürk Üniversitesi

Pamukkale Üniversitesi

FIrat Üniversitesi

Kilis 7 Aralık Üniversitesi

Ankara Üniversitesi 


\section{IÇINDEKILER / CONTENTS}

\section{Prof. Dr. Firdevs GÜNEŞ}

Konuşma Öğretimi Yaklaşım ve Modelleri

Speech Teaching Approaches and Models

doi number: 10.14686/BUEFAD.201416205

\section{Barış ÇUKURBAŞı - Prof. Dr. Aytekin IŞMAN}

Öğretmen Adaylarının Dijital Yerli Özelliklerinin Incelenmesi (Bartın Üniversitesi Örneği)

Examination of Teacher Candidates' Digital Natives Features (Example of Bartın University)

doi number: 10.14686/BUEFAD.201416206

Yrd. Doç. Dr. Süleyman GÖKSOY - Doç. Dr. Engin ASLANARGUN

Denetim Sürecinde Eğitim Denetmenlerinin Davranışları

Behaviours of Supervisors in the Process of Supervision

$55-77$

doi number: 10.14686/BUEFAD.201416207

Arş. Gör. Yunus ÖZYURT - Doç. Dr. Altay EREN

Fen Bilgisi Öğretmen Adaylarının Öğretmenlik Mesleğine ve Kopya Çekmeye Yönelik Tutumlarının Görünümü

Profiles of Pre-Service Science Teachers' Attitudes towards the Teaching Profession and Cheating doi number: 10.14686/BUEFAD.201416208

\section{Yrd. Doç. Dr. Sefa DÜNDAR}

The Investigation of Spatial Skills of Prospective Teachers with Different Cognitive

Bilissel Stilleri Farklı Ogretmen Adaylarının Uzamsal Becerilerinin Incelenmesi

doi number: 10.14686/BUEFAD.201416209

Yrd. Doç. Dr. Abdulkerim KARADENiz

Eleştirel Okuma Özyeterlilik Algısı Ölçeğinin Geçerlilik ve Güvenirlik Çalışması

Critical Reading Self-Efficacy Perception Scale Validity and Reliability Study

doi number: 10.14686/BUEFAD.201416210

Yrd. Doç. Dr. Ayşen KARAMETE - Öğr. Gör. Hüseyin GÜNEŞ

İlköğretim Seçmeli Satranç Dersi Başlangıç Düzeyi Birinci Basamak Bilgisayar Destekli Öğretim Tasarımı

Primary School First Grade Beginner Level Chess Course Computer-Aided Instructional Design

doi number: 10.14686/BUEFAD.201416211

Doç. Dr. Fahri TEMizYÜREK - Arş. Gör. Arzu ÇEVIK

Mustafa Ruhi Şirin'in Çocuk Edebiyatı Sahasındaki Eserlerinin Dil ve Kavram Bağlamında İncelenmesi

Examination of Mustafa Ruhi Sirin's Works in Field of Children's Literature According to Context of Language

Concept

doi number: 10.14686/BUEFAD.201416212

Dr. Gizem KARAOĞLAN YILMAZ - Dr. Ramazan YILMAZ - Arş. Gör. Barış SEZER

Üniversite Öğrencilerinin Güvenli Bilgi ve İletişim Teknolojisi Kullanım Davranışları ve Bilgi Güvenliği Eğitimine Genel Bir Bakış

Secure Information and Communication Technology Usage Behavior of University Students and an Overview

to Information Security Training

$176-199$

doi number: 10.14686/BUEFAD.201416213 


\section{IÇINDEKILER / CONTENTS}

\section{Yrd. Doç. Dr. Erdal TAŞLIDERE}

Kavramsal Değişim Yaklaşımının Doğru Akım Devreleri Konusundaki Kavram Yanılgılarının Giderilmesine Etkisi

Effect of Conceptual Change Instruction on Remedying Misconceptions Concerning Direct Current Circuits doi number: 10.14686/BUEFAD.201416214

\section{Dr. H. Tuğba ÖzTÜRK}

Küreselleşme ve Ağ Toplumları Odağında Bilgi ve Illetişim Teknolojileri ile Eğitim Education with Information and Communication Technologies in the Scope of Globalisation and Network Society doi number: 10.14686/BUEFAD.201416215

Yrd. Doç. Dr. Serkan TiMUR - Şirin YILMAZ - Yrd. Doç. Dr. Betül TiMUR Fen ve Teknoloji Öğretmenleri İle Öğretmen Adaylarının Fen Deneylerinin Amaçlarını Kavramaya Yönelik Tutumlarının İncelenmesi Investigating Science and Technology Teachers' and Pre-Service Teachers' Attitudes towards Understanding the Objectives of Science Experiments doi number: 10.14686/BUEFAD.201416216

\section{Fazilet Eda YILMAZ - Gülşah TOPALOĞLU - Mustafa AKYÜZLÜER}

Grupla Yapılan Müzik Etkinliğinin Otizmli Çocukların Sosyal Becerilerine Etkisinin Betimlenmesi

Description of the Effect of Musical Activity with Group on Social Skills of Children with Autism doi number: 10.14686/BUEFAD.201416217

Yrd. Doç. Dr. Özcan Erkan AKGÜN - Şirin KÜçÜK

Barış ÇUKURBAŞI - İsmail TONBULOĞLU

Sözel veya Görsel Baskın Öğrenme Stilini Belirleme Ölçeği Türkçe Formunun Geçerlik ve Güvenirlik Çalışması

Validity and Reliability Study of the Visual versus Verbal Style of Processing Scale Turkish Form doi number: 10.14686/BUEFAD.201416218

Arş. Gör. Ruhşen ALDEMiR - Doç. Dr. Enver TATAR Teknoloji Destekli Matematik Eğitimi Hakkında Yayınlanan Makalelerinin İncelenmesi An Analysis of Articles on Technology Assisted Mathematics Education doi number: 10.14686/BUEFAD.201416219

İsmail TONBULOĞLU - Prof. Dr. Aytekin IŞMAN

Öğretmenlerin Sosyal Ağları Kullanım Profillerinin İncelenmesi

Exploring Teachers' Social Network Usage

doi number: 10.14686/BUEFAD.201416220

Arş. Gör. Dr. Osman çiMEN - Prof. Dr. Mehmet YILMAZ Dönüşümsel Öğrenme Kuramına Dayalı Çevre Eğitiminin Biyoloji Öğretmen Adaylarının Çevre Sorunlarına Yönelik Algılarına Etkisi The Influence of Transformative Learning Based Environmental Education on Preservice Biology Teachers' Perception of Environmental Problems doi number: 10.14686/BUEFAD.201416221

Doç. Dr. İ. Halil TÜRKER - Yrd. Doç. Dr. Fatih ÖZDEMiR Resim-İş Eğitimi Programları Grafik Ana Sanat Ders İçerikleri ve İşleniş Biçimleri Course Outlines and Teaching Styles at Graphic Design Lessons at Fine Arts Education Departments doi number: 10.14686/BUEFAD.201416222 


\section{IÇINDEKILER / CONTENTS}

\section{Yrd. Doç. Dr. Süreyya GENÇ}

Sanat Eğitiminde Eğitsel Oyunların Önemi

Importance of Educational Games in Arts Education

doi number: 10.14686/BUEFAD.201416223

Doç. Dr. Lale HÜSEYNOVA

Müzik Öğretmenliği Bölümü Öğrencilerinin Keman Çalma Performanslarını Etkileyen Bazı Değişkenler

Some Variables that Affect the Violin - Playing Performance of Students in the Department of Music Teaching doi number: 10.14686/BUEFAD.201416224

\section{Yrd. Doç. Dr. Vafa SAVAŞKAN}

Eğitim Fakültesi Öğrencilerinin Günlük Tutma Alışkanlıklarının Öğrenci Görüşleri Doğrultusunda İncelenmesi

Investigate the Logging Habits of the Faculty of Education Students in Terms of Students' Opinion doi number: 10.14686/BUEFAD.201416225

Arş. Gör. Melehat GEZER - Prof. Dr. İbrahim Fevzi ŞAHIN

Yrd. Doç. Dr. Meral ÖNER SÜNKÜR - Arş. Gör. Elif MERAL

8. Sınıf Türkiye Cumhuriyeti İnkılâp Tarihi ve Atatürkçülük Dersi Öğretim Programı Kazanımlarının Revize Edilmiş Bloom Taksonomisine Göre Değerlendirilmesi

An Evaluation of the Outcomes of the 8th Grade History of Turkish Revolution and Kemalism Lesson According to Revized Bloom's Taxonomy doi number: 10.14686/BUEFAD.201416226

Prof. Dr. Firdevs GÜNEŞ - Doç. Dr. Coşkun ARSLAN - Arş. Gör. Ayşe ELiÜşÜK Atılganlık Eğitiminin Üniversite Öğrencilerinin Kişiler Arası Problem Çözme, Algılanan Sosyal Destek ve Atılganlık Düzeyleri Üzerine Etkisi 

Bartın Üniversitesi
Eğitim Fakültesi Dergisi
Cilt 3, Sayı 1, s. 456 - 474, Yaz 2014
BARTIN - TÜRIKIYE

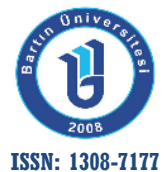
Bartin University
Journal of Faculty of Education
Volume 3, Issue 1, p. 456 - 474, Summer 2014
ISSN: 1308-7177
BARTIN - TURKEY

doi number: 10.14686/BUEFAD.201416242

\title{
Atılganlık Eğitiminin Üniversite Öğrencilerinin Kişiler Arası Problem Çözme, Algılanan Sosyal Destek ve Atılganlık Düzeyleri Üzerine Etkisi ${ }^{*}$
}

\author{
Prof. Dr. Firdevs GÜNEŞ \\ Bartın Üniversitesi \\ Eğitim Fakültesi \\ fgunes@bartin.edu.tr
}

\author{
Doç. Dr. Coşkun ARSLAN \\ Konya Necmettin Erbakan Üniversitesi \\ Ahmet Keleşoğlu Eğitim Fakültesi \\ coskunarslan@konya.edu.tr
}

\author{
Arş. Gör. Ayşe ELiüşüK \\ Bartın Üniversitesi \\ Eğitim Fakültesi \\ aeliusuk@bartin.edu.tr
}

\begin{abstract}
Özet: Atılganlık; 'girişken olmak', 'kendini açık olarak ortaya koymak', 'etkin davranmak', anlamlarına gelmektedir. Kişiler arası bir ilişki biçimi olan atılganlık, başkalarını küçük görmeden, haklarını yadsımadan kişinin kendi haklarını korumasını içermektedir. Atılganlık eğitimi ise öğrencilerin çeşitli becerilerini geliştirmeyi amaçlamaktadır. Bu çalışmada atılganlık eğitiminin üniversite öğrencilerinin kişilerarası problem çözme ve algılanan sosyal destek üzerine etkileri incelenmiştir. Araştırma ön test-son test deney ve kontrol gruplu desen olarak düzenlenmiştir. Böylece 25'i kontrol, 25'ide deney grubu olmak üzere 50 öğrenciye 9 hafta boyunca atılganlık eğitimi verilmiştir. Verilerin toplanmasında Rathus tarafından 1973'de geliştirilen ve Voltan-Acar tarafından (1980a) Türkçeye uyarlanan Rathus Atılganlık Envanteri uygulanmıştır (Akt. VoltanAcar,1980b); Ayrıca Çam ve Tümkaya'nın (2007) geliştirdiği Kişiler Arası Problem Çözme Envanteri ile Zimet, Dahlem, Zimet (1988)'in geliştirdiği, Eker, Arkar ve Yaldız'ın (2001) Türkçeye uyarladığı Çok Boyutlu Algılanan Sosyal Destek Ölçeği uygulanmıştır. Araştırmada verilen atılganlık eğitimi sonrasında, deney grubu öğrencilerinin puan ortalamalarının anlamlı düzeyde arttığı görülmüştür. Kontrol grubunda ise anlamlı düzeyde bir artış bulunmamıştır. Böylece atılganlık eğitiminin üniversite öğrencilerinin atılganlık, kişilerarası problem çözme ve algılanan sosyal destek üzerinde olumlu etkisi olduğu sonucuna ulaşılmıştır.
\end{abstract}

Anahtar Kelimeler: atılganlık, kişiler arası problem çözme, algılanan sosyal destek

\section{The Impact of Assertiveness Training on Interpersonal Problem Solving Perceived Social Support and Assertiveness of University Students}

\begin{abstract}
Assertiveness has some different meanings such as 'to be enterprising', revealing yourself as clear' and 'behaving effective'. Assertiveness, a type of interpersonal relationship, includes protecting ones rights without ignoring other people' rights or underestimating them. Assertiveness training aims to develop students' various type of skills. In this study, the impact of assertiveness training on interpersonal problem solving and perceived social support of university students was investigated. The research was designed as pre-test post-test experiment and control group study. Thus, 50 students ( 25 of them in the experiment group and 25 of them in control group) were given assertiveness training for 9 weeks. In data collection, Rathus Assertiveness Inventory which was developed by Rathus in 1973 and adapted to Turkish by VoltanAcar in (1980a) was applied. In addition, Interpersonal Problem Solving Scale developed by Çam ve Tümkaya in 2007 and Multidimensional Perceived Social Scale developed by Zimet, Dahlem, Zimet. (1988) and adopted to Turkish by Eker Arkar and Yaldız in 2001 was used. After assertiveness training it was seen that the mean scores of experimental group students were increased significantly. There was not any significant increase in control group. Hence, it is concluded that assertiveness training has a positive effect on interpersonal problem solving and perceived social support on university students.
\end{abstract}

Key Words: Assertiveness, Interpersonal Problem Solving, Perceived Social Support

\footnotetext{
* Bu araştırma, Bartın Üniversitesi Bilimsel Araştırma Projeleri Koordinatörlüğü tarafından desteklenmiştir. (Proje No: BAP-2011-2-31)
} 
Giriş

İletişim becerileri insanların yaşamında önemli bir yere sahiptir. Bireyler iletişim becerileri sayesinde düşündüklerini başkalarına aktarmaktadırlar. Böylece iletişim becerileri sosyal ilişkilere yansımakta belirleyici olmaktadır. Sosyal becerileri geliştirmede de önemli olan iletişim becerileri kişilerarası problem çözmeyi kolaylaştırmaktadır. Bireyin iletişimindeki tutum ve davranışlarını şekillendiren bir eğitim, kişilerin öfkeli, huzursuz ve rahatsız edici duygularla baş etmesini sağlayarak; sakin, rahat, mutlu ve doyum sağlayıcı bir yaşam sürmesini ve karşılaştıkları problemlerin üstesinden gelebilme yeteneklerini artıracaktır (Kamaraj, 2004). Bunun için uygun bir eğitim verilmelidir. Bu eğitimde de çocuğun içinde yaşadığı topluma uyum sağlayabilmesi için atılganlık, problem çözme, iş birliği, sorumluluk, uyum kendini kontrol etme, ilişkiyi başlatma ve sürdürme, grupla bir işi yürütme, duygularını ifade etme ve plan yapma gibi sosyal becerilerin kazandırıması gerekmektedir.

Atılganlık, "başkalarını küçük görmeden, onların haklarını yadsımadan bireylerin kendi haklarını koruyabilmeleri için geliştirilen bir çeşit kişiler arası ilişkiler biçimi" olarak tanımlanmaktadır (Voltan-Acar, 1980a). Voltan-Acar (1980b), “assertiveness" sözcüğünün Türkçede tam karşılığının bulunamadığını belirterek; iddialı, atılgan, girişken, kendini ortaya koyan sözcüklerinin "assertiveness" sözcüğünün bir kısmını karşıladığını belirtmiştir. Çulha ve Dereli'ye göre (1987) “Assertiveness" sözcüğü Türkçede "atılganlık”la karşılanmaktadır. Atılganlık; 'girişken olmak', 'kendini açık olarak ortaya koymak', 'etkin davranmak', anlamlarına gelmektedir (Baltaş ve Baltaş, 1986).

Atılgan bireyler, söylemek istediklerini net bir şekilde ifade edebilen sakin, huzurlu, empati duygusu olan, karşısındakine saygı gösteren, başkalarını önemseyen olumlu ve olumsuz düşüncelerini söyleyebilen kişilerdir (Öksüz, 2004). Atılgan yaklaşım; başkalarının küçük görmeden onların haklarını yadsımadan kişinin kendi haklarını koruyabilen kişiler arası ilişki biçimi olarak tanımlanmıştır (Alberti ve Emmons, 1976). Lazarus (1973), atılgan davranışın özelliklerini şöyle sıralamıştır: "Hayır diyebilme yeteneği, isteyebilme, ricada bulunabilme yeteneği, olumlu ve olumsuz duyguları ifade edebilme yeteneği, bir davranışı başlatabilme, sürdürebilme ve sona erdirebilme yeteneği."

Atılganlığı özellikle kişiler arası ilişkinin niteliğinin artırılmasında önemli bir uyum ögesi olarak değerlendirmek, sosyal beceri bağlamında önem kazanmıştır. Sosyo-kültürel ve psikolojik doğası ile çok yönlü araştırmalara konu olan atılganlık kavramı, birçok boyutta incelenmiş ve inceleme sonucunda elde edilen bulgular çerçevesinde atılganlığı geliştirebilecek 
ön koşulların oluşturulması ile bu davranışın öğretilebileceği ortaya çıkmış, böylece eğitim programları giderek daha popüler olmaya başlamıştır. Atılganlığın aynı zamanda kişiler arası problem çözme yeteneğini de olumlu yönde etkileyeceği belirtilmiştir. Kişiler kendini sakin, huzurlu hissederlerse problem çözmeye de sakin ve rahat bir şekilde bakacak ve daha kolay ve esnek bir şekilde problemlerle baş edebilme yetenekleri artacaktır. Bu bağlamda öncelikle kişiler arası problem çözmenin tanımlanması yerinde olacaktır:

Kişiler arası problem çözmeyi tanımlamak için öncelikle problemin tanımının yapılması gerekir. Problem, kişinin şimdiki bulunduğu durum ile bulunmak istediği durum arasındaki fark olarak ifade edilmektedir (Nezu, Nezu ve D’Zurilla, 2007). Bingham (1998) problemi bireyin istediği hedefe ulaşmak için önüne çıkan engel olarak tanımlarken, problem çözmeyi belli bir amaca başlamak için karşılaşılan güçlükleri ortadan kaldırmaya yönelik bir süreç olarak tanımlar. Problemin algısı kişilere göre farklılaşır ve bu farklılık oldukça önemlidir. Bir kişi için problem olan bir durum bir başkası tarafından için problem olarak görülmeyebilir. Bir durumun problem olarak görülmesinin nedenlerini Nezu ve ark (2007) şöyle sıralamışlardır: Yenilik ve aşina olmayış, zorluk, birbiriyle çelişen hedefler, yetenek eksikliği, kaynak eksikliği, ne yapılacağının bilinememesi (belirsizlik), duygusal sıkıntılar; kişi sonucun verdiği duygusal sıkıntıdan rahatsız olabilir. Saygıı (2000)'ya göre bireyin problem çözmeye bakış açısı çözme becerisi üzerinde etkilidir. Bunun yanında kişinin değer, inanç, tutum, ihtiyaç, beklentiler, ide probleme bakış açısını değiştirir.

Problem çözme ile ilgili yapılan pek çok araştırmada problem çözme becerisinin, iletişim becerileri, sosyal destek, demokratik anne baba tutumu, tükenmişlik düzeyi arasındaki ilişkiler çalışıımıştır (Topal, 2011).

Bu bağlamda kişiler arası problem çözme bireysel farklıııtan doğan problemleri çözümleyerek sosyal açıdan uyum sağlamak olarak tanımlanmıştır (Pellegrini ve Urbain, 1986). Western (1999), problem çözme süreci üç aşamada tanımlar:

1. Başlangıç durumu (problemle karşılaşma): Bireyler sorunla ilk karşılaştığı anda verdikleri tepkiler önemlidir: Problemi kolay ya da zor olarak algılayabilirler. Problemin kabullenilmesi aşamasıdır.

2. İşlem durumu (problemi çözmek için işlemlerde bulunma): Kişi burada var olan problemi çözmek ve arzuladığı duruma ulaşmak için girişimde bulunur. 
3. İstenen duruma ulaşma (problemin ortadan kalkması): Doğru yöntemlerle sorun çözülmüştür ve yeni problemle karşılaşıldığında işlem tekrar devam eder.

Öğülmüş'e (2001) göre kişiler arası çatışma aslında bir kişiler arası problem durumudur. Nedenleri farklı olmakla birlikte kişilerarası problem, "etkileşimde bulunan taraflardan en az birinin mevcut etkileşim biçimi ile ideal etkileşim biçimi arasındaki farkı algıladığı, bu fark yüzünden gerginlik hissettiği, gerginliği ortadan kaldırmak için girişimlerde bulunduğu, ancak girişimlerinin engellendiği bir durum olarak tanımlanmaktadır. Kişiler arası problemlerin çözümü, kişiler arası iletişimin etkili olup olmamasına bağlıdır (Çam, 1997). Atılganlık ve kişiler arası problem çözme aynı zamanda kişinin çevresini nasıl algıladığıyla ilgili bir durumdur. Kişinin çevresindeki insanları nasıl algıladığı hem problem çözme yeteneklerini hem de atılganlık düzeylerini etkileyecektir.

Atılganlık ve kişiler arası problem çözme becerisini geliştiren bir diğer öğe ise bireylerin yakın çevreleri, aileleri ve arkadaşlarından algıladıkları sosyal destektir. Son yıllarda kültürleşme sürecinde sosyal desteğin rolünde önemli bir artış olmuştur (Stone-Feinstein ve Ward, 1990). Destekleme sürecinde bireylerin aile üyelerinin, akrabalarının ve arkadaşlarının varlığı yakın ilişkiler kurmada ve devam ettirmede önemli bir rol üstlenmiştir. (Cortes, 1995 ). íki tip sosyal destekten bahsedilir, bunlar alınan ve algılanan sosyal destektir. Algılanan sosyal destek iyi oluşun önemli bir yordayıcısıdır (Patel, 1992).

Sosyal destek en önemli kaynağını çevreden sağlar. Sosyal destek stresle ve olumsuz yaşantılarla başa çıkma konusunda bireye kaynak sağlar. Arkadaş ve aileden algılanan sosyal destek her yönüyle stresle başa çıkma konusunda önemli bir rol oynar. Buna ek olarak sosyal destek güçlü aile ve arkadaşlar arasındaki bağııık aile ve arkadaşlar arasında karşılıklı yardım sağlama alışveriş ve destekleyici ilişkiler ve duyguları ifade eder (Cohen, Doyl ve Skoner, 1997).

Sosyal desteğin sağladığı tavsiye ve cesaretlendirme bireylerin problem çözmede ve bilgi aramada gücünü artırır. Bu teknikler çeşitli stresrlerle baş edebilme ve olumlu kabul sürecinin ele alınmasına yardımcı olabilir. Sosyal desteği ölçmek için arkadaşlar aile ve diğerlerinden algılanan sosyal destek olmak üzere üç değişkene bakılır. Bu ayrıca kişinin ilişkilerindeki bireysel ve sosyal davranışları anlamamızı sağlar. Problem çözme, başa çıkma ve sosyal destek psikolojik stresin yönetilmesi bilişin ve davranışın değiştirilmesi konusunda belirleyicilerdendir.(Kohlman, Weidener, Dotzauer ve Burns, 1997). 


\section{Amaç}

Bu çalışmada amaç olarak atılganlık eğitiminin Bartın Üniversitesi Eğitim Fakültesi öğrencilerinin atılganlık, kişiler arası problem çözme ve algılanan sosyal destek düzeylerine etkisinin belirlenmesi amaçlanmıştır. Araştırmanın Bartın Üniversitesi Eğitim Fakültesi öğrencilerine yol göstermesi ve iletişim becerilerini artırması hedeflenmektedir. Eğitime katılan öğrencilerin atılganlık, probleme olumlu yaklaşmaları, yapııı problem çözme, kendine güvenmeleri sorumluluk alma, sebatkâr yaklaşım, arkadaş, aile ve özel birinden algılanan sosyal destek düzeylerinin artması amaçlanmıştır.

\section{Denence}

Deney grubundaki üniversite öğrencilerinin atılganlık eğitimi aldıktan sonra kontrol grubuna göre;

1. Atılganlık becerilerinin yükseleceği,

2. Kişiler arası problem çözme becerilerinin artacağı,

3. Algılanan sosyal destek puanlarının yükseleceği hipotezi kabul edilmiştir.

\section{Yöntem}

Araştırma ön test-son test kontrol gruplu desen olarak düzenlenmiştir. Araştırmanın deney ve kontrol grubunu Bartın Üniversitesi Eğitim Fakültesinde 2012- 2013 eğitim öğretim güz döneminde öğrenim gören öğrencilerinden oluşmaktadır. Atılganlık, kişilerarası problem çözme ve algılanan sosyal destek ile ilgili bir araştırma yapılacağı Bartın Üniversitesi Eğitim Fakültesi öğrencilerine duyurulmuştur. Araştırmaya katılım gönüllülük esasına dayandırılmıştır. Araştırmaya katılmak isteyen 100 öğrenci içerisinden uygulanan Rathus Atılganlık Envanteri, Kişiler Arası Problem Çözme Envanteri, Çok Boyutlu Algılanan Sosyal Destek Ölçeklerinden aldıkları puanlar doğrultusunda birbirlerine denk puan ortalamalarına sahip 58 öğrenci seçilmiştir. Öğrenciler yirmi dokuzar kişi olmak üzere kontrol ve deney gruplarına ayrılmıştır. Deney grubuna 9 hafta süren atılganlık eğitimi uygulanmıştır. Araştırma süresince, eğitimlere devam edemeyen 4 kişi deney grubundan çıkarılmıştır, sürekli devam eden 25 kişi ile eğitim sonlandırılmıştır. Araştırma örnekleminin eşleştirilmesi amacıyla kontrol grubundan rastgele seçilen 4 kişi çıkarılmıştır. Eğitim sonunda 25'i kontrol ve 25'i deney grubu (Bartın Üniversitesi Eğitim Fakültesi öğrencileri ) olmak üzere öğrencilere son test uygulamaları yapılmıştır.

Deney ve kontrol gruplarına ait betimleyici istatistikler 
Atılganlık Eğitiminin Üniversite Öğrencilerinin Kişiler Arası Problem Çözme...

Firdevs GÜNEŞ - Coşkun ARSLAN - Ayşe ELİÜşÜK

Tablo 1: Kontrol ve deney gruplarına ait betimleyici istatistikler

\begin{tabular}{ccc|ccc}
\hline \multicolumn{3}{c|}{ Kontrol Grubu } & \multicolumn{3}{c}{ Deney grubu } \\
\hline Cinsiyet & $\mathbf{N}$ & $\mathbf{\%}$ & Cinsiyet & $\mathbf{N}$ & $\%$ \\
\hline Kız & 11 & 41,9 & Kız & 10 & 48,38 \\
Erkek & 14 & 58,06 & Erkek & 15 & 51,61 \\
Toplam & 25 & 100 & Toplam & 25 & 100,0 \\
\hline Yaş & $\mathbf{N}$ & $\mathbf{\%}$ & Yaş & $\mathbf{N}$ & $\%$ \\
\hline 18 & 4 & 12.9 & 18 & 3 & 9.6 \\
19 & 14 & 61.29 & 19 & 15 & 67.74 \\
20 & 7 & 16.12 & 20 & 7 & 22.58 \\
Toplam & 25 & 100.0 & Toplam & 25 & 100.0 \\
\hline Sınıf & $\mathbf{N}$ & $\mathbf{9}$ & Sınıf & $\mathbf{N}$ & $\%$ \\
\hline 1 & 16 & 64 & 1 & 18 & 72 \\
\hline 2 & 9 & 36 & 2 & 7 & 28 \\
\hline Toplam & 25 & 100 & Toplam & 25 & 100 \\
\hline
\end{tabular}

Tabloda 1'de de görüldüğü gibi deney ve kontrol grubu 25'er öğrenciden oluşmaktadır. Öğrencilerin yaş, cinsiyet ve sınıf özellikleri arasında gerekli denge sağlanmıştır.

Tablo 2: Deney Ve Kontrol Gruplarının Rathus Atılganlık Envanteri, Kişiler Arası Problem Çözme Envanteri ve Algılanan Sosyal Destek Ölçeği Ön Testinden Elde Edilen Mann-Whitney U Testi ile Incelenmesi

Tablo 2: Kontrol ve deney gruplarının Atılganlık, kişilerarası Problem çözme ve Algılanan Sosyal destek puan ortalamalarına ilişkin ön test karşılaştırması

\begin{tabular}{|c|c|c|c|c|c|c|c|}
\hline & & & $\mathrm{N}$ & Sıraort. & Sira top. & $U$ & $P$ \\
\hline \multicolumn{2}{|c|}{ Atılganlık } & Kontrol grubu & 25 & 25.26 & 631.50 & 306.5 & .91 \\
\hline \multirow{10}{*}{ 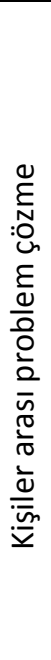 } & \multirow{2}{*}{$\begin{array}{c}\text { Probleme } \\
\text { olumsuz } \\
\text { yaklaşım }\end{array}$} & Kontrol grubu & 25 & 25.04 & 626 & \multirow[b]{2}{*}{301} & \multirow[b]{2}{*}{.82} \\
\hline & & Deney grubu & 25 & 25.96 & 649 & & \\
\hline & \multirow{2}{*}{$\begin{array}{c}\text { Yapıcı } \\
\text { problem } \\
\text { çözme }\end{array}$} & Kontrol grubu & 25 & 27.36 & 684 & \multirow[b]{2}{*}{266} & \multirow[b]{2}{*}{.37} \\
\hline & & Deney grubu & 25 & 23.64 & 591 & & \\
\hline & \multirow{2}{*}{$\begin{array}{c}\text { Kendine } \\
\text { güvensizlik }\end{array}$} & Kontrol grubu & 25 & 25.42 & 635 & \multirow{2}{*}{310.50} & \multirow{2}{*}{.97} \\
\hline & & Deney grubu & 25 & 25.58 & 639 & & \\
\hline & \multirow{2}{*}{$\begin{array}{c}\text { Sorumluluk } \\
\text { almama }\end{array}$} & Kontrol grubu & 25 & 25.14 & 646 & \multirow{2}{*}{303.50} & \multirow{2}{*}{.86} \\
\hline & & Deney grubu & 25 & 25.86 & 629 & & \\
\hline & \multirow[t]{2}{*}{$\begin{array}{l}\text { Sebatkâr } \\
\text { yaklaşım }\end{array}$} & Kontrol grubu & 25 & 25.84 & 646 & \multirow[t]{2}{*}{304} & \multirow{2}{*}{.86} \\
\hline & & Deney grubu & 25 & 25.16 & 629 & & \\
\hline
\end{tabular}




\begin{tabular}{|c|c|c|c|c|c|c|c|}
\hline \multirow{6}{*}{ 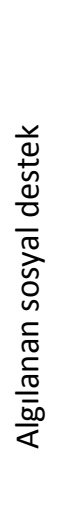 } & \multirow{2}{*}{$\begin{array}{c}\text { Yakın } \\
\text { çevreden } \\
\text { algılanan } \\
\text { sosyal destek }\end{array}$} & Kontrol grubu & 25 & 25.30 & 632.50 & \multirow[b]{2}{*}{307.50} & \multirow[b]{2}{*}{.92} \\
\hline & & Deney grubu & 25 & 25.70 & 642.50 & & \\
\hline & \multirow{2}{*}{$\begin{array}{l}\text { Aileden } \\
\text { algılanan } \\
\text { sosyal } \\
\text { destek }\end{array}$} & Kontrol grubu & 25 & 25.84 & 646 & \multirow[b]{2}{*}{304.00} & \multirow[b]{2}{*}{.87} \\
\hline & & Deney grubu & 25 & 25.16 & 629 & & \\
\hline & \multirow{2}{*}{$\begin{array}{c}\text { Arkadaş } \\
\text { algılanan } \\
\text { sosyal destek }\end{array}$} & Kontrol grubu & 25 & 26.18 & 654.50 & \multirow[b]{2}{*}{295.50} & \multirow[b]{2}{*}{.74} \\
\hline & & Deney grubu & 25 & 24.82 & 620.50 & & \\
\hline
\end{tabular}

Düşük atılganlık becerisi gösteren üniversite öğrencilerinden atılganlık eğitimine katılanlarla, böyle bir programa katılmayanların uygulama sonrasındaki rathus atılganlık, algılanan sosyal destek ve kişiler arası problem çözme ölçeklerinden aldıkları puanlar Man Witney U- testi sonuçları Tablo 2'de verilmiştir. Buna göre kontrol ve deney gruplarının, ön test sonuçlarında atılganlık, algılanan sosyal destek ve kişiler arası problem çözme becerileri arasında anlamlı bir fark olmadığı görülmüştür. Atılganlık (U=306.5, p>.05) Kişiler arası problem çözme (probleme olumsuz yaklaşım ( $U=301, p>.05)$ yapıcı problem çözme $(U=266, p>05)$ kendine güvensizlik $(U=310.50, p>.05)$ sorumluluk almama $(U=303.50, p>.05)$ sebatkar yaklaşım $\mathrm{U}=304, \mathrm{p}>.05$ )) ve algılanan sosyal destek (yakın çevreden algılanan sosyal destek $(\mathrm{U}=307.50, \mathrm{p}>.05)$ aileden algılanan sosyal destek $(\mathrm{U}=304.00, \mathrm{p}>.05)$ arkadaştan algılanan sosyal destek (U=295.50, p>.05)) sıra ortalaması dikkate alındığında deney ve kontrol gruplarının atılganlık, kişiler arası problem çözme ve algılanan sosyal destek puan ortalamaları arasındaki farkın anlamlı olmadığı görülmektedir. Bu sonuç iki grubun birbirlerine benzer özelliklere sahip olduğunu ortaya koymaktadır.

\section{Atılganlık Eğitimi}

Bu çalışmada kullanılan eğitim modeli ve etkinlikler, alıştırmalar Responsible Assertive Behavior (Jakubowki ve Lange, 1978)'dan alınmıştır. Atılganlık Eğitimi Programı'nda toplam 9 oturum boyunca eğitim verilmiştir. Her oturum 90 dakikadan oluşmaktadır. Bu etkinlikler aşağıda belirtilmiştir.

\section{Birinci Oturum:}

Tanışma, yaka kartlarının oluşturulması, grup kurallarını ve bu çalışmadan neler beklendiğini öğretmek. 
Atılgan, çekingen ve saldırgan davranışların tanımlanması, Grup üyelerine atılgan, çekingen ve saldırgan davranışların farkını göstermek ve ayırt etmeleri için uygulama firsatı vermek.

ikinci oturum:

Atılganlığın sözsüz mesajlarını kullanabilmek, sözsüz iletişimin günlük yaşamımızdaki önemini göstermek.

Atılganlığın sözsüz mesajlarını kullanabilme, sözsüz davranışların ve atılgan, çekingen, saldırgan davranışların sözsüz mesajlarının neler olduğunu göstermek. Grup üyelerinin sözsüz davranışlarının farkına varmalarını sağlamak ve atılgan davranışları övmeyi öğretmek.

Üçüncü Oturum:

Atılgan davranışlarını övmeye teşvik etmek. İzin vermezse, karşısındakinin onu ezemeyeceği, haklarını ihlal edemeyeceği fikrini vermek. Üyelere atılgan, çekingen ve saldırgan davranışları rol yaparak uygulamaları için fırsat tanımak ve yanlış anlaşılmaları düzeltmek.

\section{Dördüncü Oturum:}

Atılganca ricada bulunma ve ricayı reddetme, Olumlu ve olumsuz duyguları ifade etme Atılganca iltifat etmeyi ve iltifata olumlu karşılık vermeyi öğretmek. Aynı fikirde olmadığını göstermek, nedenini sorma ve selam verme yollarını, faydalarını öğretmek.

\section{Beşinci Oturum:}

Üyelerin birbirleri hakkındaki olumlu ve olumsuz duygu ve düşünceleri doğrudan doğruya birbirlerine söylemelerini ve olumsuz duygu ve düşünceleri hoşgörü ile karşılamalarını sağlamak.

Üyelerin farklı ses tonlarının farkına varmalarını sağlamak.

\section{Altıncı Oturum:}

Ben dili ile sen dilinin ve olumlu ile olumsuz ben dilinin farkını göstermek. Düşünce, duygu ve davranış arasındaki ilişki hakkında bilgi sahibi olma, 
Yedinci Oturum:

Üyelerin atılganca davranmalarını engelleyen gerçek dışı düşüncelerini tanımalarını ve bu düşüncelerini değiştirmelerini sağlamak.

Grup üyelerini rahatlatmak, vücutlarındaki kasların farkına varmalarını sağlamak ve gerek duydukça gerçek yaşamlarında da uygulamaları için teşvik etmek.

\section{Sekizinci Oturum:}

Atılganca davranmalarını engelleyen gerçek dışı düşüncelerin, duyguların ve davranışların tanımlamalarını sağlamak.

Öfkelenmeden ve başkalarını incitmeden hayır diyebilme, atılganlık eğitimi, eğitimcinin tavır ve eğitim şekli hakkındaki görüş ve önerileri almak.

\section{Dokuzuncu oturum:}

Eğitimin değerlendirmesini yapmak (Çulha ve Dereli 1987).

Her oturumun sonunda öğrencilerin izlenimleri alınıp oturumda kazandıklarını günlük hayatta nasıl uygulayacakları tartışılmıştır. Ayrıca, bir sonraki oturuma kadar o oturumda üzerinde durulan kazanımları ailede, öğrenci yurdunda, okulda, arkadaş ilişkilerinde kullanmaları istenmiş ve bir sonraki oturumun başında bu yaşantılar paylaşıımıştır.

\section{Veri Toplama Araçları}

Araştırmada kullanılan veri toplama araçları ve özellikleri aşağıda verilmektedir:

1. Rathus Atılganlık Envanteri: Rathus Atılganlık Envanteri (RAE) 30 maddeden oluşan bir ölçek olup, Türkçe'ye Voltan-Acar (1980b) tarafından uyarlanmış ve ölçeğin geçerlik sonucu .70; güvenirlik sonucu ise .77 olarak bulunmuştur. Ölçekten alınan puanlar -90 ile +90 arasında değişmektedir. Çekingenliğe doğru uzanan uç -90 'a, atılganlığa doğru uzanan uç +90 'a ulaşmaktadır. Bu araştırmada ölçeğin araştırma grubu için Cronbach Alpha ile hesaplanan güvenirlik katsayısı .78 olarak bulunmuştur. Dinçyürek, Çağlar ve Birol, (2010) araştırmalarında +10 puan üzerindeki sonuçların atılganlığı belirttiğini kabul etmişlerdir; bu çalışmada da söz konusu değer kabul edilmiştir.

2. Kişiler Arası Problem Çözme Envanteri: Kişiler Arası Problem Çözme Envanteri: Envanter, 18-30 yaşları arasındaki üniversite öğrencilerinde problem çözme yaklaşım ve becerilerini ölçmek için Çam ve Tümkaya (2007) tarafından geliştirilen bir araçtır. Envanter beş alt ölçekten ve toplam elli maddeden oluşmaktadır. Maddelerin 1 (hiç uygun değil) ile 5 
(tamamıyla uygun) arasında olmak üzere beşli değerlendirme seçenekleri vardır. Her bir alt ölçek için elde edilen yüksek puan kişiler arası problem çözmeyle ilgili özelliğin yüksek olduğunu göstermektedir. Envanterin yapılan faktör analizi çalışmasında kişiler arası problem çözmeyle ilgili varyansın toplam \% 38,38'ini açıklayan beş faktör elde edilmiştir. Faktörler Probleme Olumsuz Yaklaşma (POY), Yapııı Problem Çözme (YPÇ), Kendine Güvensizlik (KG), Sorumluluk Almama (SA) ve Israrcı-Sebatkâr Yaklaşım (I-SY) alt ölçekleri olarak adlandırılmıştır. Her bir alt ölçekte yer alan madde sayısı sırasıyla 16, 16, 7, 5 ve 6'dır. Maddelerin yer aldıkları alt ölçeklerin toplam puanlarıyla hesaplanan korelasyon değerleri de .22 ile .74 arasında değişmektedir. Envanterin alt ölçek puanlarının iç tutarlılık Cronbach alfa kat sayıları POY=.91, YPÇ $=.88, K G=.67, S A=.74$ ve I-SY=.70'tir. Envanterin dört hafta ara ile 60 öğrenciye iki defa uygulanması sonucunda hesaplanan test tekrar test korelasyon değerlerinin ise alt ölçekler için sırasıyla $.89, .82, .69, .76$ ve .70 olduğu gözlenmiştir (Çam ve Tümkaya, 2007).

3. Çok Boyutlu Algılanan Sosyal Destek Ölçeği: Çok Boyutlu Algılanan Sosyal Destek Ölçeği (ÇBASDÖ): Ölçek Zimet ve arkadaşları (1988) tarafından bireylerin aile, arkadaş ve yaşamlarındaki özel insanlardan aldıkları sosyal desteğin yeterliğine ilişkin algılarını değerlendirmek amacıyla geliştirilmiştir. Toplam 12 madde ve üç alt ölçekten oluşmaktadır. Her bir alt boyut dört maddeyi içermektedir. Ölçeğe verilebilecek yanıtlar 1 (kesinlikle katılıyorum) ile 7 (kesinlikle katılmıyorum) arasında değişmektedir. Ölçek Türkçeye Eker, Arkar ve Yaldız (2001) tarafından uyarlanmıştır. Ölçeğin Türkçe formunun Cronbach alfa katsayıları aile, arkadaş, özel insan ve toplam ölçek puanı için sırasıyla $.94, .85, .90$ ve .85 olarak bulunmuştur.

\section{Verilerin analizi}

Elde edilen verilerin analiz edilmesinde örneklem sayısı n<30 olduğundan (S.P.S.S.18.0); grup içi farklııkların karşılaştırılmasında Wilcoxon testi; iki grup arasındaki farklılıkları incelemek amacıyla Mann-Whitney $U$ testi kullanılmıştır (Remzi, Recai, Yıldırım ve Bayraktaroğlu, 2002).

\section{Bulgular}

Araştırmada atılganlık eğitimi programına katılan üniversite öğrencileri ile programa katılmayanlar arasındaki atılganlık, kişiler arası problem çözme ve algılanan sosyal destek düzeyleri arasında ilişki olup olmadığını belirlenmesi hedeflenmektedir. Toplanan verilerin istatistiksel işlemleri yapılmış ve bu işlemler sonucunda ortaya çıkan bulgular 3 tabloda gösterilmiştir. Araştırma sonunda elde edilen bulgular aşağıda sırasıyla verilmektedir: 
Atılganlık Eğitiminin Üniversite Öğrencilerinin Kişiler Arası Problem Çözme...

Firdevs GÜNEŞ - Coşkun ARSLAN - Ayşe ELİÜŞÜK

Tablo 3 Kontrol grubunun Rathus Atılganlık, kişilerarası problem çözme ve algılanan sosyal destek ölçeğinden elde edilen ön test ve son test verilerinin Wilcoxon Eşleştirilmiş Çiftler işaretlenmiş sıra sayıları testi ile incelenmesi

Tablo 3: Kontrol grubunun ön test-son test karşılaştırması

\begin{tabular}{|c|c|c|c|c|c|c|c|}
\hline & & Kontrol Grubu & $\mathrm{N}$ & Sıra ort. & $\begin{array}{l}\text { Sira } \\
\text { top. }\end{array}$ & Z & $P$ \\
\hline \multirow{3}{*}{\multicolumn{2}{|c|}{ Atılganlık }} & Negatif sıra & 10 & 16.50 & 165 & \multirow{3}{*}{-.07} & \multirow{3}{*}{.95} \\
\hline & & Pozitif sıra & 15 & 10.67 & 160 & & \\
\hline & & Eşit & & & & & \\
\hline \multirow{18}{*}{ 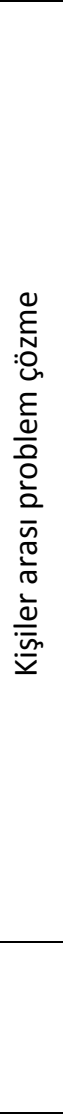 } & \multirow{3}{*}{$\begin{array}{l}\text { Probleme } \\
\text { olumsuz } \\
\text { yaklaşım }\end{array}$} & Negatif sıra & 8 & 11.94 & 95.50 & \multirow{3}{*}{-1.82} & \multirow{3}{*}{.07} \\
\hline & & Pozitif sıra & 17 & 13.50 & $\begin{array}{c}229.5 \\
0\end{array}$ & & \\
\hline & & Eşit & & & & & \\
\hline & \multirow{3}{*}{$\begin{array}{l}\text { Yapıcı } \\
\text { problem } \\
\text { çözme }\end{array}$} & Negatif sıra & 11 & 14.05 & $\begin{array}{c}154.5 \\
0 \\
\end{array}$ & \multirow{3}{*}{-.13} & \multirow{3}{*}{.90} \\
\hline & & Pozitif sıra & 13 & 11.19 & $\begin{array}{c}145.5 \\
0\end{array}$ & & \\
\hline & & Eşit & 1 & & & & \\
\hline & \multirow{3}{*}{$\begin{array}{c}\text { Kendine } \\
\text { güvensizlik }\end{array}$} & Negatif sıra & 14 & 13.04 & $\begin{array}{c}182.5 \\
0\end{array}$ & \multirow{3}{*}{-.54} & \multirow{3}{*}{.59} \\
\hline & & Pozitif sıra & 11 & 12.95 & $\begin{array}{c}142.5 \\
0 \\
\end{array}$ & & \\
\hline & & Eşit & & & & & \\
\hline & \multirow{3}{*}{$\begin{array}{l}\text { Sorumluluk } \\
\text { almama }\end{array}$} & Negatif sıra & 10 & 17.20 & 172 & \multirow{3}{*}{-.26} & \multirow{3}{*}{.79} \\
\hline & & Pozitif sıra & 15 & 10.20 & 153 & & \\
\hline & & Eşit & & & & & \\
\hline & \multirow{3}{*}{$\begin{array}{l}\text { Sebatkar } \\
\text { yaklaşım }\end{array}$} & Negatif sıra & 7 & 8.57 & 60 & \multirow{3}{*}{-.80} & \multirow{3}{*}{.42} \\
\hline & & Pozitif sıra & 10 & 9.30 & 93 & & \\
\hline & & Eşit & 8 & & & & \\
\hline & \multirow{3}{*}{$\begin{array}{c}\text { Yakın } \\
\text { çevreden } \\
\text { algılanan } \\
\text { sosyal destek } \\
\end{array}$} & Negatif sıra & 10 & 13.36 & 187 & \multirow{3}{*}{-1.12} & \multirow{3}{*}{.26} \\
\hline & & Pozitif sıra & 14 & 11.30 & 113 & & \\
\hline & & Eşit & 1 & & & & \\
\hline \multirow{6}{*}{ 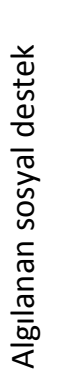 } & \multirow{3}{*}{$\begin{array}{c}\text { Aileden } \\
\text { algılanan } \\
\text { sosyal destek }\end{array}$} & Negatif sıra & 11 & 16.09 & 177 & \multirow{3}{*}{-.40} & \multirow{3}{*}{.69} \\
\hline & & Pozitif sıra & 14 & 10.57 & 148 & & \\
\hline & & Eşit & & & & & \\
\hline & \multirow{3}{*}{$\begin{array}{l}\text { Arkadaştan } \\
\text { algılanan } \\
\text { sosyal destek }\end{array}$} & Negatif sıra & 9 & 13.39 & $\begin{array}{c}120.5 \\
0 \\
\end{array}$ & \multirow{3}{*}{-.20} & \multirow{3}{*}{.84} \\
\hline & & Pozitif sıra & 13 & 10.19 & $\begin{array}{c}132.5 \\
0\end{array}$ & & \\
\hline & & Eşit & 3 & & & & \\
\hline
\end{tabular}

Tablo 3'e bakıldığında kontrol grubunun ön test-son test atılganlık ( $Z=-.07, p>.05)$ kişiler arası problem çözme (probleme olumsuz yaklaşım $(Z=-1.82, p>.05)$ yapıcı problem çözme $(Z=-.13, p>.05)$ kendine güvensizlik $(Z=-.54, p>.05)$ sorumluluk almama $(Z=-.26, p>.05)$ sebatkar 
yaklaşım ( $\mathrm{Z}=-.80, \mathrm{p}>.05)$ ), algılanan sosyal destek (aileden algılanan sosyal destek $(\mathrm{Z}=-.40$, $p>.05)$ yakın çevreden algılanan sosyal destek $(Z=-1.12, p>.05)$ ve arkadaştan algılanan sosyal destek ( $\mathrm{Z}=-.20, \mathrm{p}>.05))$ puan ortalamaları arasındaki farkın anlamlı olmadığı görülmektedir. Bu sonuç uygulama zamanı içerisinde kontrol grubunun bu özellikler açısından değişmediğini göstermektedir.

Tablo 4 Deney Grubunun Rathus Atılganlık Envanteri, Kişiler Arası Problem Çözme Envanteri vee Algılanan Sosyal Destek Ölçeğinden Elde Edilen Ön Test ve Son Test Verilerinin Wilcoxon Eşleştirilmiş Çiftler İ̧aretlenmiş Sıra Sayıları Testi ile Incelenmesi

Tablo 4: Deney grubunun ön test-son test karşılaştırması

\begin{tabular}{|c|c|c|c|c|c|c|c|}
\hline & & Deney Grubu & $\mathrm{N}$ & Sira ort. & Sira top. & Z & $\mathrm{p}$ \\
\hline \multirow{3}{*}{\multicolumn{2}{|c|}{ Atılganlık }} & Negatif sıra & 2 & 2.50 & 5 & \multirow{3}{*}{-3.51} & \multirow{3}{*}{.00} \\
\hline & & Pozitif sıra & 16 & 10.38 & 166 & & \\
\hline & & Eşit & 7 & & & & \\
\hline \multirow{15}{*}{ 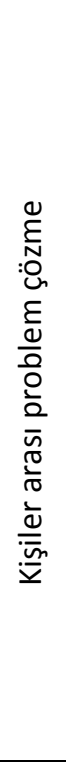 } & \multirow{3}{*}{$\begin{array}{l}\text { Probleme } \\
\text { olumsuz } \\
\text { yaklaşım }\end{array}$} & Negatif sıra & 21 & 14.43 & 303 & \multirow{3}{*}{-3.78} & \multirow{3}{*}{.00} \\
\hline & & Pozitif sıra & 4 & 5.50 & 22 & & \\
\hline & & Eşit & 0 & & & & \\
\hline & \multirow{3}{*}{$\begin{array}{l}\text { Yapıcı problem } \\
\text { çözme }\end{array}$} & Negatif sıra & 4 & 6.50 & 26 & \multirow{3}{*}{-3.67} & \multirow{3}{*}{.00} \\
\hline & & Pozitif sıra & 21 & 14.24 & 299 & & \\
\hline & & Eşit & 0 & & & & \\
\hline & \multirow{3}{*}{$\begin{array}{l}\text { Kendine } \\
\text { güvensizlik }\end{array}$} & Negatif sıra & 20 & 13.78 & 275.50 & \multirow{3}{*}{-3.59} & \multirow{3}{*}{.00} \\
\hline & & Pozitif sıra & 4 & 6.12 & 24.50 & & \\
\hline & & Eşit & 1 & & & & \\
\hline & \multirow{3}{*}{$\begin{array}{l}\text { Sorumluluk } \\
\text { almama }\end{array}$} & Negatif sıra & 21 & 13.55 & 284.50 & \multirow{3}{*}{-3.88} & \multirow{3}{*}{.00} \\
\hline & & Pozitif sıra & 3 & 5.17 & 15.50 & & \\
\hline & & Eşit & 1 & & & & \\
\hline & \multirow{3}{*}{$\begin{array}{l}\text { Sebatkâr } \\
\text { yaklaşım }\end{array}$} & Negatif sıra & 5 & 7.70 & 38.50 & \multirow{3}{*}{-3.19} & \multirow{3}{*}{.00} \\
\hline & & Pozitif sıra & 19 & 13.76 & 261.50 & & \\
\hline & & Eşit & 1 & & & & \\
\hline \multirow{9}{*}{ 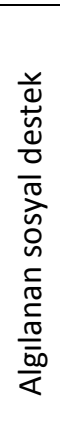 } & \multirow{3}{*}{$\begin{array}{l}\text { Yakın çevre } \\
\text { algılanan sosyal } \\
\text { destek }\end{array}$} & Negatif sıra & 3 & 7.50 & 22.50 & \multirow{3}{*}{-3.65} & \multirow{3}{*}{.00} \\
\hline & & Pozitif sıra & 21 & 13.21 & 277.50 & & \\
\hline & & Eşit & 1 & & & & \\
\hline & \multirow{3}{*}{$\begin{array}{c}\text { Aileden algılanan } \\
\text { sosyal destek }\end{array}$} & Negatif sıra & 2 & 7.75 & 15.50 & \multirow{3}{*}{-3.62} & \multirow{3}{*}{.00} \\
\hline & & Pozitif sıra & 20 & 11.88 & 237.50 & & \\
\hline & & Eşit & 3 & & & & \\
\hline & \multirow{3}{*}{$\begin{array}{c}\text { Arkadaştan } \\
\text { algılanan sosyal } \\
\text { destek }\end{array}$} & Negatif sıra & 2 & 4.50 & 9 & \multirow{3}{*}{-3.82} & \multirow{3}{*}{.00} \\
\hline & & Pozitif sıra & 20 & 12.20 & 244 & & \\
\hline & & Eşit & 3 & & & & \\
\hline
\end{tabular}

Tablo 4'e bakıldığında deney grubunun ön test-son test atılganlık $Z=-3.51, p<.001$ kişiler arası problem çözme ( Probleme olumsuz yaklaşım ( $Z=-3.78, p<.001)$ yapıcı problem çözme $(Z=-$ $3.67, p<.001)$ kendine güvensizlik $(Z=-3.59, p<.001)$ sorumluluk almama $(Z=-3.88, p<.001)$ sebatkâr yaklaşım $(Z=-3.19 p<.001)$ ), algılanan sosyal destek (yakın çevreden algılanan sosyal destek $(Z=-3.65, p<.001)$ aileden algılanan sosyal destek $(Z=-3.62, p<.001)$ ve arkadaştan 
algılanan sosyal destek $(Z=-3.82, p<.001))$ puan ortalamaları arasındaki farkın anlamlı olduğu görülmektedir. Puan ortalamaları incelendiğinde Kişiler arası problem çözme envanterinin probleme olumsuz yaklaşım, kendine güvensizlik ve sorumluluk almama alt boyutlarında öğrencilerin son test puan ortalamalarının ön test puan ortalamalarından düşük olduğu görülmüştür. Atılganlık, kişiler arası problem çözme ölçeğinin alt boyutlarından yapıcı problem çözme sebatkar yaklaşım alt boyutlarında ve çok boyutlu algılanan sosyal destek ölçeğinin tüm boyutlarında, öğrencilerin son test puan ortalamalarının ön test puan ortalamalarından yüksek olduğu görülmektedir.

Tablo 5. Kontrol ve Deney Gruplarının Rathus Atılganlık Envanteri, Kişilerarası Problem Çözme ve Algılanan Sosyal Destek Ölçeği Son Testlerinden Elde Edilen Verilerin Mann-Whitney $\cup$ Testi ile incelenmesi

Tablo 5: Kontrol ve Deney Gruplarının Son Test Karşılaştırması

\begin{tabular}{|c|c|c|c|c|c|c|c|}
\hline & & & $\mathrm{N}$ & Sıra ort. & Sira top. & $U$ & $P$ \\
\hline \multirow{2}{*}{\multicolumn{2}{|c|}{ Atılganlık }} & Kontrol grubu & 25 & 19.74 & 493.50 & \multirow{2}{*}{168.5} & \multirow{2}{*}{.00} \\
\hline & & Deney grubu & 25 & 31.26 & 781.50 & & \\
\hline \multirow{10}{*}{ 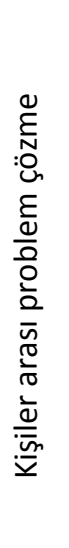 } & \multirow{2}{*}{$\begin{array}{l}\text { Probleme } \\
\text { olumsuz } \\
\text { yaklaşım }\end{array}$} & Kontrol grubu & 25 & 32.92 & 823 & \multirow[b]{2}{*}{127} & \multirow[b]{2}{*}{.00} \\
\hline & & Deney grubu & 25 & 18.08 & 452 & & \\
\hline & \multirow{2}{*}{$\begin{array}{c}\text { Yapıcı problem } \\
\text { çözme }\end{array}$} & Kontrol grubu & 25 & 18.40 & 460 & \multirow{2}{*}{135} & \multirow{2}{*}{.00} \\
\hline & & Deney grubu & 25 & 32.60 & 815 & & \\
\hline & \multirow{2}{*}{$\begin{array}{c}\text { Kendine } \\
\text { güvensizlik }\end{array}$} & Kontrol grubu & 25 & 30.96 & 774 & \multirow{2}{*}{176} & \multirow{2}{*}{.01} \\
\hline & & Deney grubu & 25 & 20.04 & 501 & & \\
\hline & \multirow{2}{*}{$\begin{array}{l}\text { Sorumluluk } \\
\text { almama }\end{array}$} & Kontrol grubu & 25 & 31.52 & 788 & \multirow{2}{*}{162} & \multirow{2}{*}{.00} \\
\hline & & Deney grubu & 25 & 19.48 & 487 & & \\
\hline & \multirow{2}{*}{$\begin{array}{l}\text { Sebatkar } \\
\text { yaklaşım }\end{array}$} & Kontrol grubu & 25 & 20.40 & 510 & \multirow{2}{*}{185} & \multirow{2}{*}{.01} \\
\hline & & Deney grubu & 25 & 30.60 & 765 & & \\
\hline \multirow{6}{*}{ 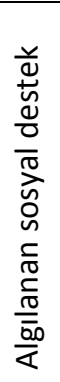 } & \multirow{2}{*}{$\begin{array}{c}\text { Yakın çevreden } \\
\text { algılanan } \\
\text { sosyal destek } \\
\end{array}$} & Kontrol grubu & 25 & 19.36 & 484 & \multirow[b]{2}{*}{159} & \multirow[b]{2}{*}{.00} \\
\hline & & Deney grubu & 25 & 31.64 & 791 & & \\
\hline & \multirow{2}{*}{$\begin{array}{c}\text { Aileden } \\
\text { algılanan } \\
\text { sosyal destek }\end{array}$} & Kontrol grubu & 25 & 19.62 & 490.50 & \multirow[b]{2}{*}{165.5} & \multirow[b]{2}{*}{.00} \\
\hline & & Deney grubu & 25 & 31.38 & 784.50 & & \\
\hline & \multirow{2}{*}{$\begin{array}{l}\text { Arkadaştan } \\
\text { algılanan } \\
\text { sosyal destek }\end{array}$} & Kontrol grubu & 25 & 20.68 & 517.00 & \multirow[b]{2}{*}{192} & \multirow[b]{2}{*}{.01} \\
\hline & & Deney grubu & 25 & 30.32 & 758.00 & & \\
\hline
\end{tabular}

Tablo 5 incelendiğinde Kontrol ve deney gruplarının son test atılganlık ( $U=168.5$, $\mathrm{p}<.001)$ kişiler arası problem çözme (Probleme olumsuz yaklaşım $(\mathrm{U}=127, \mathrm{p}<.001$ ) yapıcı problem çözme $(U=135, p<.001)$ kendine güvensizlik $(U=176, p<.05)$ sorumluluk almama $(U=162, p<.001)$ sebatkar yaklaşım $(U=185, p<.05))$, Algılanan sosyal destek (yakın çevreden algılanan sosyal destek $(U=159, p<.005)$, aileden algılanan sosyal destek $(U=165.5, p<.005)$ ve arkadaştan algılanan sosyal destek $(U=192, p<.05))$ puan ortalamaları incelendiğinde kişiler arası problem çözme ölçeğinin alt boyutlarından probleme olumsuz yaklaşım, kendine 
güvensizlik, sorumluluk almama boyutlarında deney grubundaki öğrencilerin puan ortalamalarının kontrol grubundaki öğrencilerin puan ortalamalarından düşük olduğu görülmüştür. Ancak atılganlık, kişiler arası problem çözme ölçeğinin alt boyutlarından yapıcı problem çözme ve sebatkâr yaklaşım ve çok boyutlu algılanan sosyal destek ölçeğinin tüm boyutları arasındaki farkın anlamlı olduğu bulunmuştur. Puan ortalamaları incelendiğinde atılganlık, kendine güvensizlik, yakın çevre aile ve arkadaştan algılanan sosyal destek açısından deney grubundaki öğrencilerin puan ortalamalarının kontrol grubundaki öğrencilerin puan ortalamalarında yüksek olduğu görülmektedir.

\section{Tartışma}

Araştırma sonucunda atılganlık eğitiminin deney grubu öğrencilerinin atılganlık, kişiler arası problem çözme envanterinin alt boyutlarından yapıcı problem çözme, sebatkâr yaklaşım ve çok boyutlu algılanan sosyal destek envanterinin alt boyutlarından yakın çevre, aile ve arkadaştan algılanan sosyal destek düzeyleri üzerinde olumlu bir etkisinin olduğu ortaya çıkmıştır. Araştırmada uygulanan atılganlık eğitiminin kişiler arası problem çözme ölçeğinin alt boyutlarından probleme olumsuz yaklaşım, kendine güvensizlik ve sorumluluk almama alt boyutları üzerinde ise negatif bir etkisi olduğu görülmüştür. Ayrıca kontrol ve deney grupları arasında yapılan son test karşılaştırmasında da deney grubunun atılganlık, aile ve arkadaştan algılanan sosyal destek puan ortalamalarından anlamlı düzeyde yüksek olduğu bulunmuştur. Bu sonuçlar uygulanan eğitimin öğrencilerin atılganlık, kişilerarası problem çözme ve algılanan sosyal desteğe olumlu yönde etkilediğini göstermektedir.

Yapılan literatür taramasında atılganlık eğitimi ve algılanan sosyal destek arasındaki ilişkiyi inceleyen çalışmalara rastlanmıştır. Voltan- Acar (1980b) yaptığı çalışmada atılganlık eğitiminin kişilerin atılganlıklarını ve iletişim becerilerini olumlu yönde etkilediğini bulmuştur. Bowlby (1992) sosyal desteğin engellenme ve problem çözmeyle ilgili sorunların üstesinden gelmeyi kolaylaştırdığını ve kendi ayakları üzerinde durabilme kapasitesini artırdığını ifade etmiştir. Gürçay (1995) liseye devam eden öğrenciler üzerinde yaptığı çalışmada algılanan sosyal destek ve atılganlık değişkenlerinin uyumsuz karar verme stilleri ile negatif ilişkili olduğunu bulmuştur. Şahin (1998) iletişim becerileri eğitiminin çocukların atılganlık düzeyine pozitif yönde ilişki ve yalnızlık düzeyini ise negatif yönde ilişki bulmuştur Budak (1999) lise öğrencileri ile yaptığı çalışmada algılanan sosyal destek arttıkça, problem çözme becerisinin de arttığını bulmuştur. Görüldüğü gibi bu çalışmaların sonuçları araştırma sonunda elde edilen bulgularla benzer bulguları ortaya koymuşlardır. 
Algılanan sosyal destek ve kişiler arası problem çözme arasındaki ilişkiyi inceleyen çalışmalar ise şöyle sıralanmıştır. Lawrance ve Walter (1973) Rathus atılganlık envanteri ve davranışsal problem çözme testi, ön tets son test olarak verilmiştir. Sonuçta her iki ölçekten de alınan puanlar yükselmiştir. Beahr ve ark ( 1990) algılanan yönetici desteğinin iş tatmini ne etki ettiğini de mümkün dür. Yöneticiler çalışanlar tarafından yapıyı harekete geçirici, hedef belirleyici, problem çözen, sosyal ve maddi destek sağlayan performansa ilişkin geri bildirim yapan kişiler olarak algıladıklarında çalışanların daha az belirsizlik yaşamaktadır ve çalışanların iş tatmini daha yüksek olmaktadır. Korkut (2002) lise öğrencilerinin problem çözme becerileri üzerine yaptığı çalışmada anne ve babadan algılanan sosyal destek ile problem çözme becerisi arasında anlamlı farklılık bulunmuştur. Ünüvar (2003) lise öğrencilerinin aile ve arkadaşlarından algıladıkları sosyal destek düzeyinin problem çözme becerileri üzerindeki etkisi araştırmış ve algılanan sosyal destek düzeyi arttıkça problem çözme becerilerinin arttığı bulunmuştur. Türkmen (2004) Er ve erbaşların intihar olasılıkları ile ruhsal durum, sosyal destek ve problem çözme becerilerini arasındaki ilişkiyi incelediği çalışmada problem çözme becerisi düşük olan erbaş ve erlerin intihar olasılıklarının daha yüksek olduğunu görmüştür. Lirio, P., Lituchy T. R., Monserrat, S. I., Olivas-L., Miguel R., Duffy, Jo A., Fox, S., Gregory, A.,Punnett, B.J. ve Santos, N. (2007) yaptıkları çalışmada sosyal destek bir insanın diğerine, problemlerini çözmesi ve kendini iyi hissetmesi için katkı sağlaması ve yardımcı olması olarak tanımlamıştır. Arslan (2009) lise öğrencilerinin algıladıkları sosyal destek ile sosyal problem çözme becerileri arasındaki ilişkiyi incelemiştir. Algılanan sosyal destek ile sosyal problem çözme becerileri arasında anlamlı bir ilişki bulunmuştur.

$\mathrm{Bu}$ araştırmada elde edilen bulgular ve literatürdeki bilgiler araştırmanın hipotezini destekler niteliktedir. Bu araştırmanın bulguları araştırmada uygulanan atılganlık eğitiminin, atılganlık, kişiler arası problem çözme ve algılanan sosyal destek düzeyini artmasında etkili bir eğitim yöntemi olduğu görülmüştür.

\section{Sonuç ve Öneriler}

Atılganlık eğitiminin öğrencilerin iletişim sırasında kişiler arası problem çözme becerisi ve algılanan sosyal destek düzeylerini olumlu yönde etkilediği ortaya çıkmıştır. Bu nedenle uygulanan rehberlik etkinliklerinin atılganlık eğitimine ihtiyaç duyan bireylere uygulanabilir olduğu görülmektedir. 
1. Bu çalışma üniversite öğrencileri üzerinde gerçekleştirilmiştir. Çatışma ve iletişime dayalı grup rehberliğinin diğer yaş gruplarında da uygulanması ve etkililiğinin incelenmesi faydalı olacaktır.

2. Sosyal ilişkileri yetersiz ve sınırlı olan bireylere bu eğitim verilerek atılganlık düzeylerinin artırılmasına destek verilmelidir.

3. Araştırma gruba verilen eğitimin uzun süreli etkilerini gözlemlemek için izleme çalışmalarının yapılması önerilmektedir.

\section{KAYNAKLAR}

Alberti, B. ve Emmons, M. (2002). Atılganlık: Kendinize Yatırım Yapın. (Çev: Katlan S.) Ankara: HYB Yayıncilık.

Altunışık,R., Coşkun,R, Yıldırım,E,Bayraktaroğlu,S.(2002)Sosyal Bilimlerde Araştırma Yöntemleri, 158-173

Arslan, Y. (2009). Lise öğrencilerinin algıladıkları sosyal destek ile sosyal problem çözme arasındaki ilişkinin incelenmesi. (Yayınlanmamış yüksek lisans tezi),Selçuk Üniversitesi, Sosyal Bilimler Enstitüsü, Konya.

Baltaş, A. ve Baltaş, Z. (1990). Stresle başa çıkma yolları, İstanbul: Remzi Kitabevi,

Bingham, A. (2004). Çocuklarda problem çözme yeteneklerinin geliştirilmesi. (A.F.

Bowlby, J. ve Mary A.(1992), Bretherton I. The origins of attachment theory, Ainsworth. Developmental Psychology, 28(5): 759-775.

Budak, B, (1999), Lise Öğrencilerinin Algılanan Sosyal Destek Düzeyi ile Problem Çözme Becerileri Arasındaki ilişki. (Yayınlanmamış Yüksek Lisans Tezi). On dokuz Mayıs Üniversitesi. Samsun

Cohen, S., Doyl, W.J., \& Skoner, D.P. (1997). Social ties and susceptibility to the common cold. Journal of the American Medical Association, 27(7), 40-44

Cortes, D.E, 1995. Variations in familism in two generations of Puerto Ricans. Hispanic Journal of Behavioral Sciences 17, 249-255

Çam, S. ve Tümkaya, S. (2006). Üniversite Öğrencilerinde Kişilerarası Problem

Çözme. Çukurova Üniversitesi Sosyal Bilimler Enstitüsü Dergisi, 15(2), 119-132.

Çulha, M ve Dereli A.A.( 1987),Atılganlık eğitimi programı. Psikoloji Dergisi, 6,21: 124-127

Eker. D, Arkar H, yaldız H (2001), Çok boyutlu algılanan sosyal destek ölçeğinin gözden geçirilmiş formunun faktör yapısı geçerlik güvenirliği. Türk Psikiyatri Dergisi, (12):17-25

Gavazzi, S.M., 1994. Perceived social support from family and friends in a clinicalsample of adolescents. Journal of Personality Assessment 62, 465-471.

Güçray, S. (1988), Bazı kişisel değişkenler, algılanan sosyal destek ve atılganlığın karar verme stilleri ile ilişkisi. Psikolojik Danışma ve Rehberlik Dergisi 2 (9), 7-16. 
Kamaraj, I. (2004). Sosyal becerileri derecelendirme ölçeği'nin Türkçeye uyarlanması ve beş yaş çocuklarının atılganlık sosyal becerisini kazanmalarında eğitici drama programının etkisi. (Yayımlanmamış doktora tezi), Marmara Üniversitesi Eğitim Bilimleri Enstitüsü, İstanbul

Kohlman, C., Weidener, G., Dotzauer, E., \& Burns, L. (1997). Gender differences in health behavior: The role of avoidant coping. European Review of Applied Psychology, 47, 115121.

Lange, A.J. ve Jakubowski, P. (1978). Responsible Assertive Behavior: Cognitive Behavioral Procedures To Trainers. USA Research Press. 184

Lazarus, A. A. (1973), On assertive behavior, Behavior Therapy, 4:697-699.

Lirio, P., Lituchy T. R., Monserrat, S. I., Olivas-L., Miguel R., Duffy, Jo A., Fox, S., Gregory, A.,Punnett, B.J. ve Santos, N. (2007). Exploring career-life success and family social support of successful women gin canada, argentina and mexico, International Journal of Career Management, 12, (1), 28-50.

Nezu, A.M., Nezu, C.M., ve D' Zurilla, T.J. (2007). Solving life' s problems: A 5 step guide to enhanced well-being, Springer Publishing Company.5.254-263

Ögülmüş S.(2001), Kişilerarası sorun çözme beceri ve eğitimi. Ankara: Nobel Yayın Dağıtım

Özver, İ., (2010) Genç yetişkinlerde intihar davranışı ile problem çözme , dürtüsellik ve atılganlık arasındaki ilişkinin incelenmesi , (Yayınlanmamış uzmanlık tezi) T.C. Sağlık bakanlığı, Bakırköy Prof. Dr. Mazhar Osman ruh sağlığı ve sinir hastalıkları eğitim ve araştırma hastanesi. İstanbul.

Öztürk, G. Ö. (2009). Illköğretim 5. sınıf öğrencilerine uygulanan atılganlık eğitimi programının öğrencilerin atılganlık düzeyine etkisi. Dokuz Eylül Üniversitesi, Eğitim Bilimleri Enstitüsü, İzmir

Patel, N., 1992. Psychological disturbance, social support and stressors: a communitysurvey of immigrant Asian women and the indigenous population. Counseling Psychology Quarterly 5, 263-277.

Pellegrini, D.S.;Urbain, E.S. (1986). An evaluation of Interpersonal cognitive problem solving training with children. Child Psychology and Psychiatry. Vol: 26, N: 1, 17-41.

Rathus, S. A. ( 1973 ) ,30-iTEM Schedule for assesssing assertive behavior,.Behavior Therapy, 4:398-406

Rathus, S. A. ve Nevit J. S. (1977), Concurrent validity of the 30- item assertiveness schedule with a psychiatric population. Behavior therapy, 8: 393-397

Saygıı, H. (2000). Problem çözme becerisi ile sosyal ve kişisel uyum arasındaki ilişkinin incelenmesi. (Yayınlanmamış yüksek lisans tezi), Atatürk Üniversitesi, Sosyal Bilimler Enstitüsü, Erzurum.

Stone-Feinstein, E., Ward, C., 1990. Loneliness and psychological adjustment ofsojourners: new perspectives on culture shock., Heterogeneity in Cross-cultural Psychology Lisse. Swets \&Zeitlinger, The Netherlands

St. Lawrence, J. S. (1973). Validation of a component model of social skills with a clinical outpatient population. Journal of Behavioral Assesment,15-27

Şahin, HN. (1998). Stresle başa çıkma. Ankara: Türk Psikologlar Derneği Yayınları 
Topla H., (2011) ,Eğitim fakültesi öğrencilerinin kişiler arası problem çözme becerileri ve yönelimleri ile fonksiyonle olmayan tutumları arasındaki ilişkinin incelenmesi, (Yayınlanmamış yüksek lisans tezi), Çukurova üniversitesi , Adana.

Türkmen, M. (2004). Erbaş ve erlerde intihar olasılığı ile ruhsal durum, sosyal destek ve problem çözme becerileri arasındaki iliksiler. (Yayınlanmamış yüksek lisanstezi), Ankara Üniversitesi, Ankara

Ugürol, Y. (2010) Atılganlık Becerilerini geliştirme eğitimi programının ilköğretim 7. sınıf öğrencilerinin zorbalığa uğrama düzeylerinin azaltılmasına etkisi, YівО örneği, (yayınlanmamış doktora tezi) Karadeniz Teknik Üniversitesi, Sosyal Bilimler Enstitüsü, Trabzon.

Ünüvar, A. (2003). Çok yönlü algılanan sosyal desteğin 15-18 yaş arası lise öğrencilerinin problem çözme becerisine ve benlik saygısına etkisi. (Yayınlanmamış yüksek lisans tezi), Selçuk Üniversitesi, Konya

Voltan-Acar N. (1980a) Grupla atılganlık eğitiminin bireylerin atılganlık düzeyine etkisi. Hacettepe Üniversitesi Sosyal Bilimler Dergisi, 3: 62-66

Voltan-Acar, N (1980b), Rathus Atılganlık Envanteri Geçerlilik ve Güvenirlik Çalışması, Psikoloji Dergisi, 10: 23-25.

Yılmaz S. (2005) ,Atılganlık eğitiminin hemşirelik öğrencilerinin atılganlık düzeylerine etkisi. ( Yayınlanmamış doktora tezi), Atatürk Üniversitesi Sağlık Bilimleri Enstitüsü, Erzurum

Zimet GD, Dahlem NW, Zimet SG. (1988) The Multidimensional Scale of Perceived Social Support. J Pers Assess,52: 30-41.

Zimet GD, Powel SS, Farley GK (1990) Psychometric characteristics of the Multidimensional Scale of Perceived Social Support. J Pers Assess, 55: 610-617. 


\section{SUMMARY}

The aim of this study was to determine the effect of the assertiveness training on students of the Faculty of Education of the University of Bartın for their assertiveness, problem solving and interpersonal levels of perceived social support. This research aims to increase communication skills and give guidance to the students of the Faculty of Education at the University of Bartın. Students who participated the assertiveness training where expeted to have skills like; positive approach to the problem, constructive problem solving, self-confidence, take responsibility, steadfast approach, increase the level of perceived social support from friends, family and the environment.

This research was arranged as a design with a pre-test-post-test control group. the experimental and control groups of the study consists of the students from Bartin University, Faculty of Education 2012 - 2013 academic year fall semester. It was announced to the students of the Faculty of Education. Assertiveness, Bartın that there will be a research about interpersonal problem solving, and perceived social support. Participation in the study was voluntary- based. The 100 students who applied to the research underwent the Rathus Assertiveness Inventory, Interpersonal Problem Solving Inventory, Multidimensional Scale of Perceived Social Support Scale and 58 students equivalent in their mean scores in line with were selected. The students were divided into control and experimental groups including 29 persons. A 9-week assertiveness training was administered to the experimental group. During the study, 4 people who were unable to attend the training were removed from the experimental group, the training was terminated with 25 ongoing presons. In order to match the study sample of the study, four persons were from the control group were selected and randomly removed. After the training, 25 students of the control and 25 students of the experimental group (Bartin University, Faculty of Education) underwent a posttest.

In conclusion the assertiveness training had positive effect of the experimental group students on their assertiveness, constructive problem solving from the interpersonal problem-solving inventory sub-dimensions, steadfast approach and multidimensional perceived social support of inventory subscales, perceived level of social support from family, friends and environment. The assertiveness training applied in the research had shown negative approach to sub-dimensions scale on the interpersonal problem-solving, negative impacts on subdimensions for self-confidence responsibility takig. The post-test comparison between experimental and control groups had shown that the assertiveness and mean scores from the social support perceived from family and friends of the experimental group were found significantly higher. These results suggest that the education applied on students has a positively effect on assertiveness, interpersonal problem solving, and perceived social support. 